\title{
Las minas del Rey Fernando: plata, oro, y la barbarie española en la retórica independentista hispanoamericana
}

\author{
Pedro GARCÍA-CARO \\ University of Oregon
}

\begin{abstract}
RESUMEN
La poesía y el periodismo fueron los medios principales en que se batió la querella dialéctica por la autonomía e independencia cultural y política de Latinoamérica a comienzos del siglo XIX. Este artículo delinea la centralidad del debate intelectual en torno a la naturaleza americana y en particular a las riquezas minerales y la denuncia criolla de la dependencia española de la plata y el oro americanos en algunas muestras destacadas del extenso corpus literario independentista. En los poemas analizados de Andrés Bello, José Joaquín Olmedo, y Bartolomé Hidalgo, el texto literario se convierte en un espacio ideal para dilucidar por un lado las mecánicas relaciones coloniales de explotación y expropiación mineral y por otro para imaginar el futuro postcolonial y el papel (o su ausencia) de la industria minera en ese nuevo escenario.
\end{abstract}

Palabras clave: minería, plata, oro, colonialismo, poesía de la independencia, periodismo, orientalismo, Leyenda Negra española, Andrés Bello, José Joaquín Olmedo, Bartolomé Hidalgo, Simón Bolívar.

The Mines of King Fernando: Silver, Gold, and Spain's Barbarism in the Discourse of Independence in Spanish America

\begin{abstract}
Poetry and journalism were two closely related forms of expression adopted by writers fighting over the cultural autonomy and political independence of Latin America at the start of the 19th Century. This article maps out the central role of the debate over natural and mineral resources as well as the Spanish dependency on American silver and gold in some of the relevant works from the Latin American poetry of independence. The poems by Andrés Bello, José Joaquín Olmedo, and Bartolomé Hidalgo analyzed here, show how literary texts became a suitable space to explore the mechanical colonial relations of mineral exploitation and expropriation, and also to imagine the postcolonial future and the role (if any) assigned to mining industries in that new scene.
\end{abstract}

Keywords: mining, silver, gold, colonialism, poetry of independence, journalism, orientalism, Spanish Black Legend, Andrés Bello, José Joaquín Olmedo, Bartolomé Hidalgo, Simón Bolívar. 
Cielito, digo que no, cielito, digo que sí, reciba, mi Don Fernando, memorias de Potosí. Bartolomé Hidalgo

(Hidalgo: 199)

El poeta rioplatense Bartolomé Hidalgo inaugura el género "gauchi-político" -expresión usada por Sarmiento1- con sus populares "Cielitos" y "Diálogos Patrióticos", coplas romanceadas en las que distintos gauchos retan al Rey de España, Fernando VII (1814-1833) restaurado como monarca absolutista tras la derrota de Napoleón. Este desafío retórico muestra la absorbente irrupción de la literatura política en la escena intelectual hispanoamericana con el colapso de las instituciones de vigilancia y control del Antiguo Régimen colonial. Las coplas irreverentes y antimonárquicas -sucede en paralelo en la península- muestran una particular tendencia a exaltar personajes populares como protagonistas del nuevo periodo político (Saurín de la Iglesia). A través de las múltiples voces socarronas y rústicas de los gauchos, Hidalgo cuestiona las prácticas políticas del despotismo ilustrado borbónico y los intentos de reconquista del Río de la Plata por parte de la desacreditada monarquía peninsular a lo largo del periodo 1810-1820. El lenguaje vulgar del campo es particularmente apropiado para formular un programa estético y político contra la metrópolis en el que lo americano represente los valores rurales de la periferia frente a la corrupción urbana de un centro en descomposición. Como ya propuso Borges, Hidalgo es el primero que encuentra en esta deliberada y radical oposición campo-ciudad el núcleo creativo de las convenciones retóricas de la poesía gauchesca. $^{2}$

El monólogo poético del gaucho de Hidalgo discurre de manera dialógica como la respuesta de un personaje rural y periférico, pero investido de la autoridad militar y moral de ser la voz del patriota, la "verdadera voz de una nación emergente." (Shumway: 68). Su obra inaugura una tradición criolla de ventrilocuismo literario, proceso por el cual poeta y narrador -o "payador"- se relacionan de manera marcadamente distinta a la equiparación más directa entre poeta y yo poético de la

${ }^{1}$ En el original Sarmiento se refiere a Hidalgo pero da el nombre de Maldonado por error como reconoció más tarde en carta privada a Echevarría (Véase Sarmiento: 51 y nota b).

${ }^{2}$ En "La poesía gauchesca" (1932) Borges propone un tema que se mantiene en posteriores trabajos: "Hidalgo descubre la entonación del gaucho" (Borges, 1996: 181). Dice Borges en su "Prólogo" con Bioy Casares: "[...] le corresponde a Hidalgo el hallazgo de algunos motivos esenciales: el diálogo entre paisanos, el ambiente sugerido por alusiones, las perplejidades del gaucho en la ciudad." (Borges et al., 1955: xi). En su edición de El "Martín Fierro" (1953), afirma que Hidalgo "maneja deliberadamente el lenguaje oral de los gauchos y aprovecha los rasgos diferenciales de este lenguaje, opuestos al urbano" (Borges y Guerrero, 1953). 
lírica tradicional. ${ }^{3}$ Con sus credenciales populares, el personaje del gaucho ocupa un espacio local de resistencia desde el cual el letrado, en este caso un poeta mulato (Núñez: 17), puede reconstruir su autoctonía y generar una narración identitaria donde sus raíces coloniales se desfiguran y borran.

En unos de sus "Cielitos" más extensos, un gaucho que pertenece a la Guardia del Monte responde al manifiesto monárquico de agosto de 1820 del Conde de Casa Flórez, representante militar de Fernando VII en el Río de la Plata. ${ }^{4}$ El gaucho enfatiza a través del tono jocoso del Cielito la superioridad intelectual y militar, las luces y coraje locales, frente a los "sonsos" (195) intentos retóricos del Rey y sus representantes de perpetuar su control sobre el antiguo espacio virreinal: "Para candil semejante / mejor es dormir a oscuras." (197) La lógica ilustrada popular y republicana transpira en las múltiples referencias al obsoleto e innecesario papel de la corona: "no se necesitan reyes / para gobernar los hombres / sino benéficas leyes." (198) Las relaciones de dependencia colonial se ven también transfiguradas con la revelación del papel pasivo, parasitario y dependiente de la metrópolis:

Lo que el Rey siente es la falta

de minas de plata y oro;

para pasar este trago

cante conmigo este coro. (199)

El gaucho se hace eco del argumento de la dependencia o adicción a los metales preciosos por parte de España, simbolizada en el absolutista rey Fernando perseguido tras la independencia efectiva por la nostalgia del tesoro perdido y caracterizado como monarca por su rechazo intransigente al nuevo status quo (Costeloe). En este punto, Hidalgo formula quizá la propuesta más ingenua y al mismo tiempo más utópica del futuro postcolonial que imagina para la nueva nación, al proponer la coincidencia de esta descolonización con el final del modelo industrial previo y con la lógica desindustrialización de los Andes y Río de la Plata:

${ }^{3}$ Para Núñez "los cielitos [de Hidalgo] no sólo cumplen papel noticioso, celebrativo o costumbrista, sino también ensayístico" (Núñez: 12).

${ }^{4}$ El título completo del cielito: "Un gaucho de la Guardia del Monte contesta al Manifiesto de Fernando VII, y saluda al conde de Casa-Flores con el siguiente cielito en su idioma." (Hidalgo), ver también Núñez. El representante de Fernando VII para el Río de la Plata José Flórez Pereyra, primer conde de Casa Flórez en esta época actuaba desde Río de Janeiro. Para ortografía y genealogía ver (Ortega y Pérez Gallardo: 206-207). Curiosamente el conde de Casa Flórez, pese a representar los intereses peninsulares parece haber abogado durante estos años en su correspondencia oficial por reformas profundas y por terminar con la mentalidad imperialista y colonial en la administración peninsular de lo que deberían ser consideradas, según él, "provincias de ultramar," un término relativamente "progresista" para la época, ver (Costeloe: 39). 
Ya se acabaron los tiempos

en que seres racionales, adentro de aquellas minas

morían como animales. (199)

Estos versos ambiguos se pueden leer o bien como un anuncio de las futuras propuestas anarquistas de clausura del pozo minero -la desindustrialización completa- o bien como la dignificación y rehumanización comunista del trabajo industrial tras su socialización. No cabe duda de que Hidalgo se adelanta en su radical visión poética en varias décadas a los movimientos sociales de la segunda mitad del XIX que propondrán también una radical revisión de las relaciones capitalistas de producción industrial. Hidalgo imagina así a finales de 1820 y a través de un discurso utópico humanista y post-industrial, una república de la Plata, argentina, pero sin plata, desprovista del fetiche mineral que asocia con la monarquía y el periodo colonial. Para Nicolas Shumway, el proyecto populista de Hidalgo configura y define la vertiente rural y federalista, la más "radical" y "progresista" del género gauchesco (Shumway: 78), que a diferencia de la representada por Ascasubi y otros autores unitarios, no está destinada a "entretener con su atraso a la élite ilustrada" (79), sino a dar voz efectiva y agencia a un nuevo ciudadano y simultáneamente crear lo que Ángel Núñez llama una "teoría de la independencia" (Núñez: 15). Esta teoría poética de la independencia propondría un horizonte postcolonial en el que la sociedad entera, y no sólo las elites criollas dirigentes, podría emanciparse de las estructuras de explotación coloniales deshaciendo el hilo mineral de dependencia congénita entre los dos hemisferios.

El uso de la voz proto-proletaria rural del gaucho, que de manera solidaria libera y humaniza al obrero industrial minero, sirve a Hidalgo para ocupar y poblar el espacio nacional a través de este acto retórico radical de alianza, colapsando las categorías de castas coloniales que habían organizado el régimen de explotación para revelar un "nosotros" subalterno de origen pre-hispánico:

Cielo, los Reyes de España

¡la puta que eran traviesos!

Nos cristianaban al grito

y nos robaban los pesos. (199)

El desplome del sistema legitimario colonial, basado en la autoridad formal de la corona y del Rey por designio divino a través de la fórmula en latín "Hispaniarum et Indiarum Rex Dei Gratia", acuñada mecánicamente en las monedas de plata emitidas tanto en Potosí como en México, genera insólitas narraciones culturales que negocian su nuevo espacio de poder a través de una revisión histórica crítica. Sin embargo, los "pesos" a que Hidalgo hace referencia, forman parte central de lo que llamo la episteme occidental mineral: un sistema que reifica y valoriza la plata como mercancía de intercambio, es decir que monetariza culturalmente este mineral, algo 
que no ocurría en las sociedades prehispánicas donde el oro y la plata pertenecían al espacio simbólico religioso (Pérez Melero: $53-54) .{ }^{5}$ El expolio colonial español de las Américas aparece en el "cielito" traducido y reducido a sus dos temas centrales clásicos: la cristianización violenta "al grito" y el saqueo mineral simbolizado en el robo monetario.

Desde sus inicios, el sistema colonial hispanoamericano, estrictamente regido por las élites peninsulares, había tenido como base el llamado "lingotismo" o mercantilismo metálico: la extracción, fundición, y exportación de los minerales preciosos para uso monetario, fundamentalmente la plata y en menor medida el oro. En este protocapitalismo hispánico - en realidad una forma de mercantilismo feudal con signos de capitalización- los múltiples atributos metafísicos de la plata y del oro, y la cultura que estas formas económicas producen, revelan un sistema epistémico mineral occidental-mediterráneo que se contrapone a la episteme mineral prehispánica en la que esos minerales se utilizan de manera ritual y ornamental y no bajo una forma monetaria en el intercambio económico. Con el establecimiento de verdaderas colonias mineras, los procesos de generación de numerario público pasaron a ser el modo de producción más visible de la economía hispana y el índice inflacionario cuyo exceso constituye la clave para entender la desindustrialización temprana, tanto en la península ibérica como en toda el área colonial española (Hamilton; Jaguaribe; Stein y Stein). ${ }^{6}$ Los únicos centros industriales del imperio pasaron a ser los núcleos de producción y exportación del metal que se vieron sometidos a un desequilibrio comercial constante y a una dependencia importadora regida y vigilada desde los centros de decisión global -Amberes, Madrid, Sevilla- y local -Lima, Potosí, Buenos Aires, Ciudad de México- erigidos estos últimos desde muy temprano en centros de intermediación, adquisición, flete, y tasación. Los centros coloniales hispanos estuvieron integrados en la red mercantil global como suministradores del erario, guardianes del tesoro, y consumidores de mercancías de uso, manufacturas fabricadas en otros lugares, desde la China $^{7}$ hasta el norte protestante donde la industrialización se orienta al abastecimiento del sur y se convierten, pues, al mismo tiempo en replicantes de los mandatos metropolitanos, pero también en pequeñas metrópolis locales a través de las estructuras virreinales. La

\footnotetext{
${ }^{5}$ Véase también Ferguson: 18-28.

${ }^{6}$ Los Stein utilizan la etiqueta "bullionism" -literalmente "lingotismo"- definida como el control exhaustivo ejercido por la corona española de las extracciones minerales de oro y plata americanos desde la boca de la mina hasta el puerto de Sevilla y que produjo una contracción permanente de la productividad industrial y agrícola peninsular y americana (7-8). Para una utilización de este término en España, ver (Martínez Ruiz et al.: 345). Curiosamente, incluso bajo el más centralizado gobierno borbónico, la financiación de la corona siguió manteniendo una dependencia directa no sólo de los impuestos sino de la deuda con América: "the king regularly found himself heavily in debt to his phenomenally wealthy subjects in America" (Irigoin y Grafe: 185).

Estudios recientes, por ejemplo, demuestran que la circulación de plata hispanoamericana en China durante el periodo colonial se mide por toneladas anuales (Irigoin).
} 
transferencia de plata del hemisferio americano, del Alto Perú (Perú, Bolivia) y de Nueva España (México), a Europa y Asia generó un espacio económico e industrial globalizado con centros y periferias desfigurados. ${ }^{8}$ La ruptura de este orden colonial no es sólo un proceso de fractura entre el eje Cádiz-Sevilla-Madrid, y los espacios coloniales americanos, sino también una quiebra interna en el hemisferio occidental de este modelo de colonialismos regionales generado por el circuito del mercantilismo metálico o lingotismo.

En ese contexto, no es de extrañar que el futuro de la explotación mineral del continente americano se convirtiera en uno de los argumentos y problemas centrales de la polémica independentista. Junto con la preocupación por el futuro de la mina que vislumbramos en el poema gauchesco de Hidalgo, en la poesía independentista latinoamericana encontramos una ansiedad e incertidumbre palpables acerca del modelo económico e industrial que habrá de adoptar ese espacio postcolonial fraccionado. Es en ese punto específico de configuración del futuro postcolonial con respecto a la producción mineral, donde encontramos también un índice extraordinariamente fructífero para evaluar y definir los distintos posicionamientos y proyectos políticos criollos. Si la poesía y la prosa políticas independentistas movilizan la función simbólica del mineral, subrayando la irracionalidad e inmoralidad de su valoración, lo hacen representando negativamente las relaciones políticas y económicas surgidas en el régimen colonial, la avaricia y adicción mineral española, y proponiendo alternativas post-metálicas, agraristas y utópicas para las futuras repúblicas independientes.

La radicalidad de la voz popular de Hidalgo es más patente cuando se compara su práctica poética con la de otros autores contemporáneos hispanoamericanos que, como Andrés Bello, explotan esa misma oposición campo-ciudad con aparatos léxicos y retóricos más tradicionales. El futuro postcolonial imaginado por Bello entre 1823 y 1826 desde su largo exilio londinense está dedicado a la domesticación y colonización agrícola de la "fecunda zona" del hemisferio occidental, huyendo de la corrupta sociedad urbana e industrial con la que se simboliza el modelo colonial. Bello, más académico y neoclásico, abraza y desea un americanismo postcolonial cuyo valor central sea como en Hidalgo el campo, pero su diálogo no tiene como protagonistas al eufórico campesino gaucho que desafía al rey, sino al poeta que exige a la Poesía que abandone ya "[...] la culta Europa, / que tu nativa rustiquez desama, / y [dirija] el vuelo adonde te abre / el mundo de Colón su grande escena." Consciente del juego irónico metatextual, Bello dirige su arenga al futuro poema que Poesía y sus Musas "deberán" escribir y cantar, y al hacerlo escribe él ese mismo poema esperado.

${ }^{8}$ Para distintos historiadores económicos es claro que el sistema monetario mercantil hispano se caracterizó por su capacidad redistributiva sobre todo dentro del espacio americano, "throughout the colonial period the overwhelming share of the American treasure was spent in the Indies" (Klein: 103; Sempat Assadourian; Irigoin y Grafe).

9 "Alocución a la poesía", 43. Todas las referencias a la obra de Bello son del primer volumen Poesías de las Obras completas de 1952. 
Si bien la "nativa rustiquez" que Bello atribuye a la poesía se debe más a su adaptación del género pastoril que a un intento protofolklorista de textualizar la realidad poética oral como hace Hidalgo, su "Alocución" aporta una visión panorámica y americanista exenta de divisiones localistas y nacionales del hemisferio occidental.

Tanto la "Alocución" como la "Silva" de Bello representan el inicio inacabado de "América", una más extensa obra poética, que quedó cortada bien por falta de inspiración (Carilla, 1977: 112) bien por desazón ante el fracaso político bolivariano y los escombros de las luchas internas tras la independencia (Gomes: 194). Posiblemente haya algo de cierto en ambos argumentos, y la pesadumbre ante la tierra quemada, los caudillismos localistas y las guerras civiles de las décadas posteriores a la independencia efectiva no fueran materia que pudiera inspirar a Bello a la creación lírica sino, como ocurrirá a otros muchos letrados hispanoamericanos de esta época, a la intervención más directa de la escritura legal (y, en su caso, también a los estudios filológicos y gramaticales) que habría de ocupar el resto de su ingente labor intelectual hasta la muerte (Jaksic).

Al comienzo de esa dilatada postguerra, Andrés Bello recupera en su "Silva a la agricultura de la zona tórrida," el antiguo imaginario del canje de la espada por el arado, del veterano guerrero tornado labrador, enalteciendo el retorno del colono criollo a las labores de la tierra americana para cerrar "las hondas / heridas de la guerra" (70). Las múltiples referencias a las largas luchas y los "tantos años de fiera / devastación y militar insulto," (72) se contraponen a la feraz natura americana, el nuevo campo de batalla criollo. Los criollos tienen como misión histórica para Bello "de nuestros padres malhadados / expia[r] la bárbara conquista." (72) Es por ello quizá que el paisaje americano de Bello no alude a la riqueza mineral sino a la agricultura como la labor ética que redimirá a los descendientes hispanos de esos "padres malhadados." Al "corregir los excesos del colonialismo" (Kaempfer) con su poema, Bello desahucia y elide la mina como espacio del pasado colonial que no conduce a la emancipación de su república de granjeros, verdadero ejército de "gentlemen farmers" criollos a la Thomas Jefferson. Bello anuncia en su geórgica tropical la épica conquista y ordenación del paisaje salvaje a manos de un agricultor cuya faena es a un tiempo expiar los excesos y culminar la implantación de la (agri)cultura occidental en las Américas: "[...] al vulgo bravío / de las tupidas plantas montaraces, / sucede ya el fructífero plantío / en muestra ufana de ordenadas haces." (71) $\mathrm{Si}$, como mostraré más adelante, la independencia continental, la ofensiva de la civilización criolla contra la barbarie colonial, se habían conceptualizado en la retórica de la década anterior como la lucha de las luces americanas contra la oscuridad de la tiranía ibera y de su "eterna servidumbre" (Olmedo, 1947a: 122), el nuevo frente, la teoría poética de la independencia que Bello evoca aparece en dimensiones más pragmáticas, pero no es por ello un reto trivial ni exento de futuras violencias neocoloniales.

Tanto Bartolomé Hidalgo como Andrés Bello representan dos respuestas políticas y poéticas alternativas al despotismo colonial dentro del extenso campo independentista, que empieza ya a vislumbrar un futuro sin España: Bello elogia al 
agricultor criollo republicano que opera como nuevo colono, ahora redimido, desprovisto ya de la codicia mineral y dispuesto a participar en una economía productiva agrícola. Más local, el proyecto de Hidalgo se hace eco de las voces mezcladas, populares, de peones y gauchos del Río de la Plata y su visión no es épica ni continental sino satírica y local, en la cual no propone un programa colonizador sino una crítica de las relaciones de poder del coloniaje, aquello que Aníbal Quijano denomina la "colonialidad del poder" (Quijano). Ambos poetas intuyen y anuncian en sus teorías poéticas de la independencia los futuros desafíos geográficos y conflictos sociales que ocuparían el hemisferio.

Amigo y aliado de Andrés Bello, José Joaquín Olmedo alude también en su "La victoria de Junín, canto a Bolívar" a las transformaciones postbélicas y la economía agrícola que imagina en esas "nuevas leyes [que] dará" "la sanguínea espada / [...] en el útil arado transformada" (Olmedo, 1947a: 133). Con el célebre poema de Olmedo culmina de manera lúcida la ambigüedad en torno a la futura explotación postcolonial de los minerales preciados americanos. $\mathrm{Y}$ ocurre en una trayectoria intelectual diferente a la de Bello: de las leyes a la poesía. Si en 1812, como diputado por Guayaquil en las Cortes de Cádiz, Olmedo había desplegado el proyecto criollo de denuncia a las instituciones y legislaciones coloniales de opresión social haciendo un extenso alegato público contra la Mita (Olmedo, 1947b), ${ }^{10}$ en su poema mantiene la denuncia de la colonización española: "sangre, plomo veloz, cadenas fueron / los sacramentos santos que trajeron" (Olmedo, 1947a: 135), al tiempo que revela una nueva solución, una nueva teoría poética de la independencia. Como Hidalgo, acude al recurso poético del ventrilocuismo, pero no es aquí un gaucho el que habla. Su poema, híbrido entre elegía y drama poético, tiene como protagonista central no a Bolívar, sino a Huayna-Cápac, el fundador de la dinastía Inca quien parece ser "el asunto del poema: él es el genio, él la sabiduría, él es el héroe, en fin" se lamenta Bolívar en su demoledora y significativa crítica a Olmedo por carta de 12 de julio de 1825 desde Cuzco (Olmedo, 1974: 100). "Un coloso que ocupa todo el ámbito y cubre con su sombra a los demás personajes" (ibid.: 100) asegura Bolívar, para quien el panegírico quizá pareciera insuficiente. Las dos cartas que el Libertador envía a Olmedo desde Cuzco revelan no sólo sus bien acreditadas capacidades intelectuales como general letrado, sino también la inmediatez con la que se suceden las dos batallas de Junín (6 de agosto, 1824) y Ayacucho (9 de diciembre, 1824), la urgencia de la escritura del poema que las exalta, y la veloz crítica privada del héroe guerrero a su "Homero." Pese a las críticas de Bolívar a la precipitación, "un gran delito del poeta," (íbid.: 100) el verdadero Deus ex machina del poema, el inca Huayna-Cápac le permite a Olmedo imaginar y justificar su propuesta postindustrial utópica. La voz

${ }^{10}$ Defiende la liberalización de la industria minera usando un argumento por un lado humanitario (25) y por otro antiintervencionista, propio del laissez faire liberal (26). Al comparar la Mita con los trabajos forzados de los penados romanos, dice Olmedo que "los indios son condenados a esas horribles y famosas fatigas sin otra culpa que la avaricia ajenas, sin otro crimen que su humildad y su mansedumbre." (28) 
fantasmática del rey Inca ofrece un contraste brillante con el ausente y monstruoso rey español, el Rey Fernando, cuyas tropas fueron finalmente vencidas en la batalla de Ayacucho, contienda que aparece amalgamada en el poema con la de Junín de unos pocos meses antes Ingeniosamente, Huayna-Cápac vaticina la victoria de Ayacucho desde el campo de Junín.

Evoca Huayna-Cápac la fabulosa exuberancia y riqueza mineral de América antes de la llegada de los españoles, cuando el oro era parte natural del paisaje cortesano, motivo ornamental de templos y palacios incas: " $¡$ Tantos horrores y maldades tantas / por el oro que hollaban nuestras plantas!" $(135)^{11}$. Recuerda también la conquista motivada por el oro en los términos convencionales, resumiendo los trescientos años de coloniaje español como "tres centurias / de maldición, de sangre y servidumbre / y el imperio regido por las Furias." (134) Tras la independencia, rechazada la máquina imperial de extracción y explotación como pesadilla del pasado, no se puede concebir fácilmente otro proyecto minero pese a que la cordillera andina atesore aún, según la voz poética narrativa al comienzo del poema, grandes depósitos minerales: "Los Andes, las enormes, estupendas / moles sentadas sobre bases de oro..." (123) En un acto de ilusionismo poético, el "oráculo" del Inca devela una visión del futuro en que esas bases doradas de los Andes podrán a un tiempo evitar el denostado y humillante trabajo del minero, y compartir sus riquezas con las nuevas naciones:

Ya las hondas entrañas de la tierra

en larga vena ofrecen el tesoro

que en ellas guarda el Sol, y nuestros montes

los valles regarán con lava de oro. (145)

El oro fluirá sólo. El augurio del rey Inca, con la imagen espectacular de la copiosa eyección natural de oro a la superficie de los valles centrales en forma de lava preciosa, resuelve la contradicción aparente del mantenimiento de la industria extractiva en una sociedad emancipada. Pese a hacer uso extenso de la iconografía prehispánica no es ésta, sin embargo, una propuesta indigenista para recuperar la "nación primordial Inca" (Díaz-Caballero: 10). Conocedor de las suspicacias de las elites criollas del antiguo virreinato del Perú, advierte Olmedo a través de su maniquí oracular incaico que no volverá el imperio Inca:

[...] mas no quisiera que el cetro de los Incas renaciera que ya se vió algún Inca, que teniendo

el terrible poder todo en su mano, comenzó padre y acabó tirano. (143)

${ }^{11}$ Todas las referencias a la "Victoria de Junín" son del texto de Olmedo La batalla de Junín, Himno a Bolívar de 1974. 
Esta advertencia de Olmedo acerca de la tiranía, vocalizada a través de HuaynaCápac, recuerda de hecho al tránsito del propio Rey Fernando que pasa de de 1808 a 1814 de ser el rey "deseado", prisionero político de Napoleón, a monarca absoluto y tirano moderno. La de Olmedo es, pues, una solución mítica y mágica, un augurio no cumplido que resuelve sólo de manera artificiosa aunque resplandeciente, la importante cuestión del papel de la Latinoamérica postcolonial en el circuito monetario mineral.

Destacados de entre el extenso corpus literario independentista, los ejemplos de Hidalgo, Bello, y Olmedo, revelan la centralidad del debate poético en torno a la riqueza natural americana y en particular a los recursos minerales y la acusación criolla de la dependencia peninsular de la plata y el oro americanos. ${ }^{12}$ Durante las guerras de independencia latinoamericanas la plata y el oro se configuraron como centros de referencia simbólicos en el debate político e intelectual sobre dos modelos económicos diferentes: el mercantilismo metálico hispano aristocrático y feudal, y el naciente capitalismo industrial burgués. Estos dos modelos productivos, asociados a dos visiones diferenciadas de la historia y de las relaciones sociales, se convierten en un vértice que divide las afiliaciones políticas -conservadoras o liberales respectivamente- y que tras el colapso imperial de 1808 se manifiestan y combaten con vigor tanto en la península como en las Américas. Ambos campos se atrincheran en las constantes guerras civiles que se vivirán en uno y otro lado del Atlántico a lo largo de todo el siglo XIX y parte del XX. Las complejas guerras de independencia son, pues, a un tiempo guerras de emancipación y guerras civiles, guerras territoriales y conflictos de clase, y suponen el intento de constitución a ambos lados del Atlántico de una modernidad política construida sobre la frágil base de la oposición entre defensores y detractores de esa misma modernidad civil. La hispanofilia de los partidos conservadores hispanoamericanos, igual que la hispanofobia del liberalismo transatlántico, es un buen índice para configurar un marco de estudio que permita comprender mejor tanto el proceso emancipatorio como el florecimiento en tan breve periodo de tiempo de una extensa serie de códigos nacionales, tanto criollos como peninsulares. ${ }^{13}$ En el centro de esta querella intelectual e identitaria se sitúa la crítica liberal y republicana al mercantilismo metálico de cuño español y a la explotación mineral de las Américas, que los republicanos hispanoamericanos, agraristas criollos y populistas gauchescos, combaten con un modelo político alternativo: el libre comercio con Inglaterra y los Estados Unidos.

La denuncia del mercantilismo despótico español interpreta el modelo económico del Antiguo Régimen a través de una serie de imágenes que subrayan la relación de dependencia patológica entre la metrópolis y sus posesiones americanas. Esta relación se representa como conducta política y económica enfermiza, aberrante, corrupta, producto de la marginalidad oriental hispana con respecto a los modelos civilizatorios

${ }^{12}$ Las pocas antologías y ediciones más conocidas que han recuperado este corpus son de difícil acceso para la enseñanza o el público lector amplio: Urbina; Carilla 1964, 1992; Barcia.

${ }^{13}$ Véanse los importantes estudios al respecto de Pike y de Sepúlveda Muñoz. 
ilustrados del norte de Europa que los patriotas liberales criollos aspiran a imitar. Para ello, los letrados criollos llevan a cabo un doble juego por el que, al tiempo que naturalizan sus posiciones políticas liberales dentro de una lógica occidental, expulsan de ella al poder hegemónico peninsular como irracional o atávico, caracterizando su dominio absolutista como una patología moral: un despotismo de tipo oriental, no estrictamente europeo y civilizado, sino bárbaro.

Se trata de la reactivación política de una antigua y persistente retórica antihispana propagada durante las guerras de religión europeas en los siglos XVI y XVII y que había dado forma primero en el norte de Europa, principalmente en Holanda e Inglaterra, y posteriormente en los escritos de la ilustración francesa durante el XVIII, a estereotipos culturales y prejuicios raciales conocidos desde comienzos del siglo XX bajo la rúbrica de la Leyenda Negra española (Juderías; Maltby, 1982: 9-11). La novedad histórica a comienzos del siglo XIX reside en el uso de lugares comunes de la Leyenda Negra tales como la codicia por el oro de los conquistadores o el tribunal de la Inquisición, por parte tanto de españoles americanos o criollos, como de españoles peninsulares, ${ }^{14}$ en lo que progresivamente pasa a configurarse como el ideario liberal hispánico. Éste demanda una nueva identidad política rechazando la tradicional asociación de lo hispano con el catolicismo inquisitorial contrarreformista, y con las prácticas económicas mercantiles y feudales asociadas con la monarquía absoluta (Álvarez Junco). ${ }^{15}$ Esos tres pilares del antiguo régimen imperial hispanoamericano, rechazados por el liberalismo, se convertirán a su vez en el estandarte de los diversos partidos conservadores o tradicionalistas, al grito de "Por Dios, la Patria, y el Rey" (Allvarez Junco: 362-364), que se traslada incluso a periodos republicanos tradicionalistas donde la figura del "Rey" se sustituye por la de cualquiera de los caudillos que ocupe la jefatura del estado.

A comienzos del XIX, en medio de la represión a las primeras formas de insurgencia armada en Hispanoamérica, se inaugura el debate "civilización o barbarie" en el que lo hispano ocupará el lugar del bárbaro en el imaginario liberal criollo. El vacío de poder tras el secuestro por Napoleón de la familia real, había obligado a una parte importante de las elites coloniales criollas, a reescribir y reinventar su lugar y sus propias historias socio-económicas en el contexto de la imparable descomposición de la máquina pluricéntrica colonial. De acuerdo con gran

${ }^{14}$ Véase por ejemplo el caso del antiguo inquisidor madrileño convertido en historiador y crítico de la Inquisición, Juan Antonio Llorente (1756-1823), cuyas obras, junto con las de Goya, grabaron según Henry Kamen "en nuestra mente la imagen que todavía hoy tenemos de la Inquisición y estuvieron en el centro de los debates y luchas de aquellos años [...]" (Kamen: 180). Véanse también sus referencias a la historia crítica escrita por los exiliados liberales españoles a su regreso a la península en los 1830s (202-205).

${ }^{15}$ Una de las primeras publicaciones del Consejo de la Hispanidad, el centro de estudios con orientación neocolonial constituido por el régimen franquista a comienzos de la década de los 1940, se dedica a la Leyenda Negra con la finalidad de "clarificar el tema [...] en su más cabal amplitud, es decir, en sus formas típicas de juicios sobre la crueldad, el obscurantismo y la tiranía política." (Carbia: 11). 
parte de la historiografía colonial, desde época muy temprana la corona había ejercido de intermediaria en las disputas entre las elites colonizadoras euroamericanas, tanto criollas como peninsulares, y era la garante del status quo en una sociedad de castas altamente estratificada. El historiador Edwin Williamson resume el pacto virreinal de coerción institucional eclesiástica y monárquica suscrito entre criollos y peninsulares como el de una doble colonialidad: "las oligarquías blancas aceptaron su estatus colonial formal como el precio que habían de pagar por el mantenimiento de ese otro y muy real colonialismo interno del que ellos eran los principales beneficiarios" (Williamson: 115). ${ }^{16}$ Esta afinidad y activa participación subalterna en la gobernación del sistema mercantil durante el periodo colonial de los agentes locales criollos -la misma que Bolívar y otros denunciarán por escasa o insuficiente- se pone sous-rature a lo largo del proceso independentista y de formación nacional.

La reescritura de la historia colonial que se lleva a cabo en pleno periodo independentista ya sea a través de la poesía, el periodismo o el discurso político se basa en un doble movimiento retórico por el cual la élite letrada liberal crea una separación entre "ellos" y "nosotros" (españoles y americanos) que busca deshacer en el plano simbólico sus raíces europeas, atribuyéndose un linaje puramente americano en el que "nuestros mayores" no son conquistadores ni colonos, sino indígenas. El espacio victimario imaginado por los criollos independentistas al comienzo de las guerras no es, como para el Bello londinense, la ciudad colonial, sus calles empedradas, los palacios, universidades, y foros de la maquinaria occidental de control de la que son parte activa, sino como anunciará Bolívar en 1815 desde su exilio en Jamaica, la mina. El letrado criollo liberal se imagina ante el vacío institucional hispano de 1808, no ya como el consumidor forzado de manufacturas indo-inglesas (el famoso té del "tea party" bostoniano), sino como el mitayo, el minero esclavizado que produce la plata de rápida exportación al área metropolitana. Leamos lo que escribió un autor anónimo de 1812:

[...] el español, ese monstruo a quien parece vomitaron las ondas del Océano en nuestras apacibles costas, para causar en ellas la desolación, horror y espanto en que nos han sumergido por tres siglos, devorado por la insaciable sed del oro, y de la plata, de ese funesto don con que la naturaleza quiso regalarnos para turbar por tantos años de sangre la inmutable tranquilidad en que vivían nuestros mayores, arrancando de su sagrado asilo a los miserables indios para trasplantarlos a los obscuros calabozos de las minas, y haciendo perecer por el trabajo, y por la dureza del castigo a la enorme población con que se inundaba el continente y sus innumerables islas apartó sus ojos sanguinarios de las riberas de la América, en

${ }^{16}$ Esta visión de la monarquía hispana, al menos hasta la llegada de los borbones tras la guerra de sucesión (1700-1715), como un agente de coordinación y una "fuerza de equilibrio" entre múltiples consejos y agentes sociales y políticos, lo que John Elliott ha llamado una "monarquía o estado compuesto" [composite monarchy] sigue siendo la interpretación más extendida (Donghi: 222; Elliott). Para un cuestionamiento del absolutismo como principio a favor de la mecánica burocrática de negociación, véase Irigoin y Grafe. 
donde había apurado las víctimas de su codicia y su furor, y los dirigió al África para arrancar de allí a esa porción de miserables, a ese montón de hermanos nuestros, que llevan hasta el día impreso en su semblante el sello de nuestra ignominia en la continuación de su pesada esclavitud. (Fúrlong Cárdiff y Gandía: 97-98)

Este fragmento pertenece a un artículo de tipo propagandístico surgido en el diario El grito del Sud en agosto de 1812, en el contexto de las actividades de la Sociedad Patriótica literaria de Buenos Ayres, y tiene como propósito doble la atribución de legitimidad a la continuación del modelo social euro-criollo, y la reapropiación simbólica y material del espacio político, en cuyo centro económico se sitúan la plata y el oro como contradictorio "funesto don." El uso del plural posesivo muestra una alta inestabilidad discursiva entre el comienzo del fragmento, donde se habla de "nuestras costas" sobre las que el monstruo español fue "vomitado," y que contrasta al final del párrafo con la referencia a la esclavitud africana como "sello de nuestra ignominia." Esta inestabilidad revela la participación activa en el tráfico esclavista del colectivo local cuyo portavoz escribe y que es al mismo tiempo, y de manera imposible, indígena natural de "nuestra" costa, hermano de africanos, pero partícipe en la continuidad de la "ignominiosa" institución esclavista. Otra de las fracturas discursivas que revelan este espacio heterotópico que construye el autor anónimo del artículo reside en la separación pronominal "nosotros-ellos" en el fragmento que describe la ruptura del orden utópico indígena: "la inmutable tranquilidad en que vivían nuestros mayores, arrancando de $s u$ sagrado asilo a los miserables indios para trasplantarlos a los obscuros calabozos de las minas" (98, mi énfasis). En la contradictoria consecución del plural histórico de primera persona "nuestros mayores" y el plural de tercera "los miserables indios," "transplantarlos" se produce el acto de prestidigitación y borradura de las circunstancias históricas y la genealogía hispana y no indígena del ensayista criollo. Estas contradicciones y discontinuidades retóricas permiten efectuar el salto retórico, la creación de lo que José Antonio Mazzotti ha llamado la "agencia criolla" (Mazzotti; Earle) $)^{17}$.

“¿De dónde descienden los españoles?” se pregunta el 27 de octubre de 1812 otro anónimo ensayista (o quizá es el mismo) que contribuye también a El Grito del Sud de Buenos Aires: “¿Dónde está la nobleza de su origen? ¿No son ellos los

${ }^{17}$ Estas contradicciones se verbalizan en el mismo número de El Grito del Sud, donde otro articulista se dirige a los esclavos africanos bonaerenses para decirles: "sois casi incapaces de conduciros desde luego por vosotros mismos, sin que antes seáis de algún modo preparados a esta repentina mutación [...] vuestros hijos, sí, vuestros hijos serán libres” (Fúrlong Cárdiff y Gandía: 100). Los anuncios públicos del periódico también nos revelan las relaciones de opresión en las que los criollos y sus esclavos seguían inmersos: "D. Juan Tomás Coguet [...] se le huyó una negra de su propiedad, llamada Felisarda, hace cinco meses, de edad de 14 a 15 años, de mediana estatura, gruesa, hocicona, color fulo, y con un diente doble en la parte inferior. Ofrece dos onzas de oro al que se la lleve, y algo más según lo merezca el trabajo de su aprensión" (156). 
descendientes de los Vándalos, Godos, Moros, Etíopes, y Judíos?" (Fúrlong Cárdiff y Gandía: 180). Se populariza en esa época el uso de la palabra "Godo" para referirse a los españoles, no tanto para denotar etnicidad más blanca o germana, sino más bien conducta bárbara y destructora de las civilizadas instituciones latinas. ${ }^{18} \mathrm{Al}$ apelativo "gótico," usado en referencia a un pasado oscurantista y medieval, se suma la antigua sospecha de prácticas religiosas y morales heterodoxas derivadas del mestizaje semita. La historia peninsular queda amalgamada y reducida a una infame mescolanza de impurezas producto de la lascivia y la violencia de pueblos caracterizados como bárbaros y salvajes. El énfasis en la mezcla de tradiciones "bárbaras" con la que se asocia lo español en la retórica independentista criolla constituye el negativo contra el que se proyecta la silueta civilizada y noble del republicanismo criollo ilustrado y neoclásico. La retórica anti-española del liberalismo criollo desarrolla así durante este primer periodo una serie de lugares comunes para hablar del régimen colonial transatlántico hispano que se pueden resumir en tres términos morales asociados a la Leyenda Negra y al orientalismo enciclopedista francés: corrupción, codicia, y tiranía. Ello permite al anónimo escritor porteño equiparar a los metropolitanos con la servidumbre doméstica africana, los esclavos que atienden la mesa criolla: "¿Qué sangre hay menos pura que la de ellos [los españoles]?” se pregunta, “¿Por qué no se miran siquiera en el espejo, para quedar convencidos por sus reverendas patas, horribles getas, y ridícula figura de que sus padres fueron negros tan tintos, y de ojos tan blancos, como los que ahora nos sirven a la mesa?" (180). Esta retórica criolla "denigrante," en el sentido literal del término, utiliza paradójicamente categorías de la tradición peninsular como la "pureza de sangre" y la "nobleza" o "hidalguía" de origen para cuestionar las credenciales metropolitanas y recolocar al criollo en el espacio superior del dominio imperial. No se trata pues de un giro epistémico emancipador sino de un desplazamiento de las jerarquizadas castas de la colonia en las que el español americano o criollo había ocupado un lugar subalterno al peninsular. A la representación de una raza española en la que se mezclan todas las posibles periferias y barbaries opuestas a la civilización occidental se suma la cita obligada al padre Las Casas como autoridad moral. Pero la recreación de los lugares comunes de la Leyenda Negra no sería completa sin la pertinaz imagen de la voracidad metálica anticristiana española: “...estas, pues, son las obras de los españoles que van a las Indias; que verdaderamente muchas, e infinitas veces por la codicia que tienen de oro han vendido, y venden hoy en este día, y niegan, y reniegan de Jesu Cristo" (178). La traición a cambio de unas cuantas monedas de oro remite no sólo al episodio concreto de Judas Iscariote, sino a la larga tradición antisemita sobre la que se basan ése y muchos otros mitos cristianos, y que se cierne aquí sobre la cabeza del español, sospechoso de ser en realidad un codicioso judío converso. Pietri.

${ }^{18}$ En los antiguos territorios virreinales de Nueva Granada y Buenos Aires, véase Uslar 
Un ejemplo concluyente de esta doble operación de occidentalización criolla y orientalización hispana lo provee la "Carta de Jamaica" (1815) de Simón Bolívar, quien compara el fallido sistema de colaboración entre el régimen colonial español y los españoles americanos con las tiranías orientales de Turquía, Persia, y China en las "que tienen organizada una opresión de que participan los súbditos en razón de la autoridad que se les confía." ${ }^{19}$ Es decir, son tiranías, pero ejercidas con el consentimiento y participación activa de los súbditos. Las Españas salen mal paradas en el orbe político orientalista que presenta Bolívar puesto que a los americanos descendientes de europeos no se les permitía ejercer los "derechos que [les] correspondían" dentro del orden colonial. El derecho vedado aparentemente a los criollos es el de participar en el ejercicio de la "tiranía", es decir en la administración y diseño del propio imperio. Por ello, Bolívar afirma que:

estábamos privados hasta de la tiranía activa, pues que no nos está permitido ejercer sus funciones. Los americanos en el sistema español que está en vigor, y quizá con mayor fuerza que nunca, no ocupan otro lugar en la sociedad que el de siervos propios para el trabajo y, cuando más, el de simples consumidores... (191)

El deseo bolivariano de ejercer o colaborar con la tiranía colonial que el despotismo omnímodo peninsular no ha tolerado, desemboca paradójicamente en la aspiración de separación que permitirá a los criollos construir un proyecto republicano liberal nacido bajo esa contradictoria marca: los agentes liberales son al mismo tiempo actores reprimidos de despotismo y colonialidad. Es por ello que el historiador Halperín Donghi apoda al proyecto ilustrado de Bolívar como un irrealizable "autoritario reino de la virtud" (Halperín Donghi: 119).

La lógica criolla bolivariana elabora la crítica al sistema borbónico de centralización de la administración colonial y reducción de las áreas de influencia criollas instalado a lo largo del siglo XVIII, posicionando simbólicamente al criollo en los márgenes sociales y productivos, un paisaje que culmina con la insólita imagen del criollo esclavizado en las entrañas de la tierra, en el interior de la mina de oro: ${ }^{20}$ “¿[...] cuál era nuestro destino? Los campos para cultivar el añil, la grana, el café, la caña, el cacao y el algodón; las llanuras solitarias para criar ganados, los desiertos para cazar las bestias feroces, las entrañas de la tierra para excavar el oro que no puede saciar a esa nación avarienta" (191-192). Bolívar resume las limitaciones de los designios imperiales sobre la población criolla, sometida a una "infancia permanente" por las restricciones en la actividad económica monopolista y el despotismo político del régimen mercantil colonial. Pero más allá de la denuncia o la rebelión contra la

${ }^{19}$ Simón Bolívar, "Carta de Jamaica” (Lecuna y Barret de Nazaris: 190-191).

20 Según Leslie Bethell y otros historiadores la propiedad de las minas, igual que la mayoría de haciendas en Nueva España -y de manera parecida en Nueva Granada- estaba en su mayoría en manos de criollos, que constituían lo que Bethell llama "la élite natural" del país (un 17,8\% de la población) en contraposición con la élite administrativa, militar, y eclesiástica colonial peninsular (un 0,2\% de la población total) (Bethell: 52-53). 
codicia y la relación subsidiaria de producción minera a la que los designios imperiales españoles habían sometido primordialmente a Nueva España y el Alto Perú, utilizándolos como verdaderos proveedores del tesoro público en caudal lingotizado o amonedado in situ, y redistribuido dentro de todo el espacio imperial, lo que la "Carta" de Bolívar revela es ese conflicto irresuelto acerca de la explotación de esas minas por las futuras repúblicas criollas que ya hemos notado en la poesía que aparecería cronológicamente unos años más tarde.

En otro momento de la "Carta", al referirse a Perú, comenta cómo allí será más difícil establecer una república moderna, puesto que "encierra dos elementos enemigos de todo régimen justo y liberal; oro y esclavos. El primero lo corrompe todo; el segundo está corrompido por sí mismo" (201). Este rechazo de Bolívar al oro como mineral que todo lo corrompe soslaya y ataca de manera simbólica la base principal de su valoración en el sistema de trueque occidental, su incorruptibilidad: el oro es por definición un mineral maleable inoxidable y altamente duradero lo cual le confiere un valor excepcional como referente de intercambio comercial (Ferguson: 24-25). La corrupción a que Bolívar se refiere es una ilustración intuitiva del concepto marxista de "fetichismo mercantil" por el cual, el valor del objeto se construye y percibe en la red social como inherente a él, borrando la historia de las relaciones laborales que han llevado a su producción y con ella, la historia de su valoración. El caso del oro -al igual que la plata- obedece bien a la descripción que Marx hace de la mercancía fetichizada cuyo valor no lo da su uso, sino su valor "místico" de ser "objetos naturales con propiedades sociales extrañas" (Marx, Fernbach y Mandel). Si toda mercancía aparece bajo el análisis marxista como "en realidad una cosa bien rara, en la que abundan matices metafísicos y preciosidades teológicas, ${ }^{21}$ la plata y el oro son el arquetipo de esta metafísica mercantil descrita por Marx, cuyos matices teológicos revelan su fetichización -y con ella la irracionalidad o corrupción- inherente al sistema de valoración mercantil capitalista.

El deseo de ascenso de una clase social específica, la emergente burguesía criolla, sitúa históricamente la "Carta" al final de las luchas entre la administración borbónica y los restos de aquel imperio compuesto heredado de los Habsburgo, una lucha en la que los criollos de momento habían salido mal parados, pero que culminaría con su victoria y la demonización final del rey absolutista Borbón par excellence: Fernando VII. A raíz de la restauración de Fernando VII en la primavera de 1814, su rechazo de las Juntas tanto peninsulares como americanas y de la Constitución de Cádiz de 1812, y la dura represión de todo cuanto sonara a constitucional o liberal, resucitará y confirmará con una energía excepcional las imágenes de la Leyenda Negra, personificada ahora en el nuevo Rey, un déspota español al estilo "oriental." No en vano el grupo de sesenta y nueve diputados absolutistas del partido eclesiástico y aristocrático, los serviles, habían suscrito el "Manifiesto de los Persas" en el que equiparaban la fidelidad de los vasallos del rey restaurado a la que suscitaba tras días

21 " [...] in reality, a very queer thing, abounding in metaphysical subtleties and theological niceties" (Marx, Fernbach y Mandel). 
de anarquía el rey de los Persas (Novella: 81 y ss., 134). La imagen orientalista de España, y con ella su Leyenda Negra de intolerancia y fanatismo, es abrazada y difundida por aquellos que desean el retorno del Antiguo Régimen y de la feudalidad perdida con el experimento constitucional. Como nos recuerda William Maltby, la leyenda no es un mito, sino una narrativa que se basa en hechos y tradiciones, exagerados o no, al fin y al cabo reales (Maltby, 1982: 18). Mientras en septiembre de 1815 , en su carta privada a un caballero británico en su exilio en la isla de Jamaica, Simón Bolívar preparaba su regreso a la lucha contra España afirmando que “...todo lo sufrimos de esa desnaturalizada madrastra. El velo se ha rasgado, ya hemos visto la luz, y se nos quiere volver a las tinieblas; se han roto las cadenas [...]" (183), en la península el triunfo del "ivivan las cadenas!", el casi incomprensible grito popular católico de apoyo al Rey Fernando, marcaba el distanciamiento y la quiebra definitivos entre los diferentes cuerpos políticos hispanos.

\section{BIBLIOGRAFÍA}

Álvarez JunCO, José.

2001 Mater Dolorosa: la idea de España en el siglo XIX. Madrid: Taurus.

BARCIA, Pedro Luis.

1982 La Lira argentina, o, Colección de las piezas poéticas dadas a luz en Buenos Aires durante la guerra de su Independencia. Buenos Aires: Academia Argentina de Letras.

BELLO, Andrés.

1826 "Silva a la agricultura de la zona tórrida", El repertorio americano (Octubre): 11 .

1952 Obras completas. Vol. 1. Caracas: Ministerio de Educación, 22 vols. BETHELL, Leslie.

1987 The Independence of Latin America. Cambridge: Cambridge University Press.

BORGES, Jorge Luis.

1996 Obras completas: (1923-1949). Vol. 1. Buenos Aires-Barcelona: Emecé, 4 vols.

Borges, Jorge Luis; Bioy Casares, Adolfo; Hidalgo, Bartolomé; AsCasubi, Hilario; CAMPO, Estanislao del; LusSiCH, Antonio D. Lussich; HERNÁNDEZ, José y LYNCH, Ventura R.

1955 Poesía gauchesca. México: Fondo de Cultura Económica.

BORGES, Jorge Luis y GUERRERO, Margarita.

1953 El "Martín Fierro". Colección Esquemas. Buenos Aires: Editorial Columba. $2^{\mathrm{a}}$ edc.

CABAllero, Jesús Díaz.

2008 "Incaísmo as The First Guiding Fiction in The Emergence of The Creole Nation in The United Provinces of Río de La Plata", Journal of Latin American Cultural Studies 17 (1):1-22. 
CARBIA, Rómulo D.

1943 Historia de la leyenda negra hispano-americana. Buenos Aires: Ediciones Orientación Española.

CARILla, Emilio.

1964 La literatura de la independencia hispanoamericana (neoclasicismo $y$ preromanticismo). [Buenos Aires: Editorial Universitaria de Buenos Aires].

1977 Estudios de literatura hispanoamericana. Bogotá: [Instituto Caro y Cuervo].

1992 Poesía de la Independencia. Caracas: Biblioteca Ayacucho.

Costeloe, Michael P.

1986 Response to revolution: imperial Spain and the Spanish American revolutions, 1810-1840. Cambridge: Cambridge University Press.

DoNGHI, Tulio Halperin.

1992 "Backward Looks and Forward Glimpses from a Quincentennial Vantage Point", Journal of Latin American Studies 24 (2):219-234.

EARLE, Rebecca.

2007 The Return of the Native : Indians and Myth-making in Spanish America, 1810-1930. Durham: Duke University Press.

ELLIOTT, J. H.

1992 “A Europe of Composite Monarchies”, Past \& Present (137):48-71.

FERGUSON, Niall.

2009 The ascent of money: a financial history of the world. London-New York: Penguin Books.

FÚRLONG CÁRDIFF, Guillermo y GANDÍA, Enrique de (eds.).

1961 Periódicos de la época de la Revolución de Mayo. Vol. 2. Buenos Aires: Academia Nacional de la Historia, 5 vols.

GOMES, Miguel.

1998 "Las silvas americanas de Andrés Bello: una relectura genologica", Hispanic Review 66 (2):181.

HALPERÍN DONGHI, Tulio.

1998 Historia contemporánea de América Latina. Madrid: Alianza. HAMILTON, Earl J.

1965 American Treasure and the Price Revolution in Spain, 1501-1650. New York: Octagon Books.

HIDALGO, Bartolomé.

2007 Obra Completa. Ed. de Olga Fernández Latour de Botas. Buenos Aires: Stockcero.

IRIGOIN, Alejandra.

2009 "The End of a Silver Era: The Consequences of the Breakdown of the Spanish Peso Standard in China and the United States, 1780s-1850s", Journal of World History 20 (2):207-243. 
IRIGOIN, Alejandra y GRAFE, Regina.

2008 "Bargaining for Absolutism: A Spanish Path to Nation-State and Empire Building", Hispanic American Historical Review 88 (2):173209.

JAGUARIBE, Hélio.

1969 La dependencia político-económica de América Latina. El Mundo del hombre Economía y demografía. México: Siglo Veintiuno Editores, $1^{\mathrm{a}}$ edc.

JAKSIC, Ivan.

2001 Andrés Bello: la pasión por el orden. Santiago de Chile: Editorial Universitaria.

JUDERÍAS, Julián.

1974 La leyenda negra: estudios acerca del concepto de España en el extranjero. Madrid: Editora Nacional.

KAEMPFER, Alvaro.

2007 "Economías de redención: 'La agricultura de la zona torrida' (1826)

KAMEN, Henry. de Andrés Bello" (Spanish), MLN 122 (2):272-293.

2008 The Disinherited: Exile and the Making of Spanish Culture, 14921975. New York: Harper Perennial.

KLEIN, Herbert S.

1998 The American finances of the Spanish empire: royal income and expenditures in colonial México, Peru, and Bolivia, 1680-1809. Albuquerque: University of New México Press.

LECUNA, Vicente y BARRET DE NAZARIS, Esther (eds.).

1929 Cartas del Libertador corregidas conforme a los originales. Vol. 1. Caracas: Lit. y Tip. del Comercio, 11 vols.

MALTBY, William S.

1971 The Black Legend in England; the development of anti-Spanish sentiment, 1558-1660, Duke historical publications. Durham, N.C.: Duke University Press.

1982 La Leyenda Negra en Inglaterra: desarrollo del sentimiento antihispánico, 1558-1660. México: Fondo de Cultura Económica.

Martínez Ruiz, Enrique; Giménez, Enrique; ARMillas Vicente, José A. y MAQUEDA ABREU, Consuelo.

1994 Introducción a la historia moderna. Madrid: Istmo.

MARX, Karl.

1993 Capital: A Critique of Political Economy. Ed. de David Fernbach y Ernest Mandel. Vol. 1. Penguin Classics, 3 vols.

MAZzoTTI, José Antonio.

2000 Agencias criollas: la ambigüedad "colonial" en las letras hispanoamericanas. Pittsburgh, PA: Instituto Internacional de Literatura Iberoamericana, Universidad de Pittsburgh. 
NOVELLA, Jorge.

2007 El pensamiento reaccionario español, 1812-1975: tradición y contrarrevolución en España. Madrid: Biblioteca Nueva.

NúÑEZ, Ángel.

1989 "Un Cielito Gaucho Contra Fernando VII", Revista de Critica Literaria Latinoamericana (RCLL) 15 (30):9-23.

OLMEDO, José Joaquín de.

1947a Poesías completas. Ed. de A. Espinosa Pólit. México: Fondo de Cultura Económica.

1947b Discurso sobre las mitas de America: pronunciado en las Córtes, en las sesion de 12 de agosto, de 1812. Ed. de Abel Romeo Castillo. Guayaquil: Universidad de Guayaquil.

1974 La batalla de Junín, Himno a Bolívar. Ed. fascímil de Rafael Bernal Medina con apéndice de crítica al poema. Bogotá: Academia Colombiana de la Historia.

ORTEGA Y PÉREZ GALLARDO, Ricardo.

1902 Estudios genealógicos. México: Impr. de E. Dublan.

PIKE, Fredrick B.

1971 Hispanismo, 1898-1936: Spanish conservatives and liberals and their relations with Spanish America. Notre Dame: University of Notre Dame Press.

PÉREZ MELERO, Joaquín.

2009 "From Alchemy to Science: The Scientific Revolution and Enlightenment in Spanish American Mining and Metallurgy", en The revolution in geology from the Renaissance to the enlightenment. Ed. de G. D. Rosenberg. Boulder: Geological Society of America.

QUIJANO, Aníbal.

2007 "Coloniality and Modernity/Rationality", Cultural Studies 21 (23):168-178.

SARMIENTO, Domingo Faustino.

1993 Viajes por Europa, África y América, 1845-1847 y diario de gastos. Ed. de Javier Fernández. Nanterre: ALLCA XX-Université Paris XCentre de Recherches Latino-Américaine, Colección Archivos, $1^{\mathrm{a}}$ edc.

SAURÍn DE LA IGLESIA, María Rosa.

1998 Cancionero liberal contra Fernando VII. Fasano: Schena Editore.

SEMPAT ASSADOURIAN, Carlos.

1983 El sistema de la economia colonial: el mercado interior; regiones y espacio económico: Carlos Sempat Assadourian. Mexico: Ed. Nueva Imagen.

SEPÚLVEDA MUÑOZ, Isidro.

2005 El sueño de la madre patria: hispanoamericanismo y nacionalismo. Madrid: Fundación Carolina-Centro de Estudios Hispánicos e Iberoamericanos. 
SHUMWAY, Nicolas.

1991 The invention of Argentina. Berkeley: University of California Press. STEIN, Stanley J. y STEIN, Barbara H. .

2003 Silver, Trade, and War: Spain and America in the Making of Early Modern Europe. Baltimore: The Johns Hopkins University Press.

URBINA, Luis G.

1910 Antología del centenario, estudio documentado de la literatura mexicana durante el primer siglo de independencia. México: Impr.

USLAR PIETRI, Arturo. de M. León Sánchez.

1986 Godos, insurgentes y visionarios. Barcelona: Seix Barral.

WILLIAMSON, Edwin.

1992 The Penguin history of Latin America. London-New York: Penguin Books. 